\title{
Constitutional Restraints on the Regulations of Scientific Speech and Scientific Research
}

\section{Commentary on "Democracy, Individual Rights and the Regulation of Science"}

\section{Robert Post}

Received: 18 August 2008/Accepted: 8 April 2009/Published online: 5 May 2009

(C) Springer Science+Business Media B.V. 2009

\begin{abstract}
The question of what constitutional constraints should apply to government efforts to regulate scientific speech is frequently contrasted to the question of what constitutional constraints should apply to government efforts to regulate scientific research. This comment argues that neither question is well formulated for constitutional analysis, which should instead turn on the relationship to constitutional values of specific acts of scientific speech and research.
\end{abstract}

Keywords First Amendment - Constitutional scrutiny · Academic freedom · Scientific speech · Scientific research · Government restriction

The question of what constitutional constraints should apply to government efforts to regulate scientific speech is frequently contrasted to the question of what constitutional constraints should apply to government efforts to regulate scientific research (Weinstein 2009). I shall argue in this comment that neither question is well formulated for constitutional analysis, which should instead turn on the relationship to constitutional values of specific acts of scientific speech and research.

\section{Government Restrictions on Scientific Speech}

To ask what constitutional constraints should apply to government regulations of "scientific speech" presupposes that there is something called "scientific speech" that merits distinctive constitutional treatment. There is no such discrete constitutional category of "scientific speech."

R. Post ( $($ )

The Yale Law School, P.O. Box 208215, New Haven, CT 06520, USA

e-mail: Robert.Post@yale.edu 
If we define "scientific speech" as the communications of "scientists" in the course of the professional practice of science, the category includes such disparate kinds of expression as (1) the publications of scientists in private scientific journals, (2) the speech of scientists in the classroom of a state university, and (3) the speech of agency scientists in the course of their employment. The First Amendment treats each of these three forms of speech in an entirely distinct manner. This is because the state's interest in regulating the speech of its administrative employees is different from its interest in regulating the speech of professors at public universities, and each of these interests is in turn different from the state's interest in regulating the speech of private persons. Constitutional analysis in each of these three cases will be controlled by the strength of relevant state interests and not by whether the speaker is a scientist or by whether the content of the regulated speech refers to science.

An environmental scientist speaking in public about global warming will receive the identical constitutional protection as will a lay person speaking about the same subject. The speech of a government clerical employee who wishes to comment on public issues will be protected by the same constitutional rules as will be applied to the speech of a government scientist who wishes publicly to bring his expertise to bear on such issues. A professor of physics will be protected by exactly the same principles of academic freedom as will a professor of English.

James Weinstein implicitly understands that "scientific speech" is not a meaningful First Amendment category. It is for that reason that he usefully focuses our attention on a single example: whether Professor Bletchley Park can publish on his web page a scientific paper that describes the decryption of the "Content Scramble System" (CSS), which is a mechanism designed to prevent copying of movies. (Weinstein 2009). The Digital Millennium Copyright Act might well render the publication of this decryption illegal.

If one carefully examines Weinstein's analysis of the Park case, it is clear that nothing in his analysis turns on the fact that Park is a scientist or that Park's speech uses technical scientific language or that Park's speech represents the practice of science. Instead Weinstein asks a generic question. Weinstein asks whether Professor Park's speech should be classified for constitutional purposes in the category of public discourse. This is not a question that turns on whether the content of Park's speech refers to scientific issues or whether Park is himself a scientist or whether the publication of the decryption code represents a scientific contribution.

I am in general agreement with Weinstein's approach. Weinstein correctly rejects what he calls the "all inclusive approach," the idea that "speech as such" deserves constitutional protection (Post 1995, 2000a). The "all inclusive approach" should be repudiated because First Amendment protection turns not merely on the substance of state interests - why a state is regulating-but also on what a state is regulating. First Amendment doctrine distinguishes between regulations of speech and regulations of action. It distinguishes between the regulation of public discourse and the regulation of commercial speech (Post 2000a). These distinctions express the idea that different kinds of speech acts will bear different relationships to the constitutional values served by the First Amendment. 
A simple formulation of the point would be this: Speech that serves the constitutional purposes of the First Amendment deserves the kind of constitutional protection that will enable it to continue to serve these purposes. To frame the issue in this way is to suggest powerful and far-reaching theoretical implications. It enables us to understand why the all inclusive approach is incorrect. Speech which does not serve the values of the First Amendment should not receive any constitutional protection at all.

Framing the issue in this way also enables us to perceive flaws in Weinstein's general approach. It suggests, for example, that we ought to reject Weinstein's distinctions between "rights" and the "general welfare," and between rights that protect "core" constitutional values and rights that are merely "instrumental" to the realization of constitutional values (Weinstein 2009). Courts protect rights in order to protect constitutional values. These values express a vision of the public good. There is thus no deep theoretical opposition between "individual rights" and the "general welfare." Nor is it helpful to distinguish between core constitutional rights and instrumental constitutional rights; courts protect rights in order to protect constitutional values. All rights are in this sense instrumental. No constitutional right ought to extend further than is necessary in order to protect a pertinent constitutional value.

An important consequence of the theoretical approach I suggest is that we ought sharply to distinguish between First Amendment coverage and First Amendment protection. (Post 2000b). First Amendment coverage to whether or not a court will determine the constitutionality of a challenged government regulation by reference to the particular doctrines of the First Amendment. The constitutionality of most forms of government regulation-for example those that control vehicular safety or environmental protection-do not raise First Amendment questions. Courts decide their constitutionality without reference to specifically First Amendment doctrines. First Amendment doctrines consist of the specialized rules formulated by courts to test whether regulations should survive scrutiny under the First Amendment. The question of First Amendment coverage refers to when courts should or should not subject state regulations to these specialized doctrinal rules.

First Amendment protection, by contrast, refers to the question of which government regulations courts should uphold and which they should strike down. Issues of First Amendment protection concern the content of the doctrinal tests that courts should apply when First Amendment coverage exists. Government regulations commonly trigger First Amendment coverage and yet are nevertheless found to be constitutional after the application of pertinent First Amendment doctrinal tests.

First Amendment doctrinal tests come in many different varieties. Sometimes First Amendment tests are categorical. Regulations enacted in order to serve purposes forbidden by the First Amendment are categorically struck down. Sometimes First Amendment tests are not categorical. They require courts to weigh the strength of governmental interests against the impact of particular regulations on constitutional values. Such tests require courts to perform precisely the sort of balancing that Professor Weinstein intimates is inconsistent with the very idea of a 
"core" First Amendment right. Yet in the United States, and indeed throughout the world, First Amendment rights are routinely protected in this way.

Applying the theoretical framework I suggest to the example analyzed by Weinstein, the first question we ought to ask is whether the application of the Digital Millennium Copyright Act to criminalize Professor Park's publication on his website of the decryption code of CSS should trigger First Amendment coverage. If First Amendment coverage is triggered, we can then proceed to the question of First Amendment protection, which asks whether the Digital Millennium Copyright Act, as applied to Professor Park, survives applicable First Amendment tests.

The central value served by the First Amendment is that of democratic selfgovernance. Most First Amendment doctrines are best analyzed as efforts to protect the forms of communication necessary for democracy (Post 2000c). Whether Professor Park's website is sufficiently connected to this value to trigger First Amendment coverage depends upon the forms of communication that we regard as necessary for the success of a democratic state.

How we answer this question depends upon our definition of democracy. I myself view democracy as a form of government in which those who are subject to law can also view themselves as the authors of law (Post 1993). In the United States we implement this ideal by subordinating government to public opinion and by guaranteeing all who are subject to law the opportunity to participate in the formation of public opinion. The concept of "public opinion" is complex, but the concept emerges with the sociological development of the public sphere.

First Amendment doctrine distinguishes between speech deemed necessary for the formation of democratic public opinion, which may be called "public discourse," and other forms of speech. Public discourse consists of communicative acts deemed necessary for the health and constitution of the public sphere, which is the precondition for the emergence of public opinion. Many forms of speech are not included within public discourse because we do not regard them as efforts to influence public opinion. Consider in this regard commercial speech, which is about selling goods; or the professional speech of a doctor to a patient, which is about diagnosing and treating illness; or the speech involved in contractual negotiations, which is about forming a contract.

Weinstein invites us to analyze the case of Professor Park, who has published speech to the general public on his website. The purpose of Park's publication is to inform public opinion and increase scientific knowledge. Park wishes to inform the public about how CSS does and does not work. The Supreme Court has correctly concluded that speech published to the general public through the World Wide Web in order to inform public opinion and increase public knowledge is public discourse. Such speech is constitutive of the public sphere. Constitutional analysis would be different if Professor Park were to have distributed his findings to a small set of subscribers who have paid for information about how to decrypt their DVDs.

It follows from this analysis that the attempt to suppress Professor Park's speech should trigger First Amendment coverage. Nothing in this analysis, however, turns on the fact that Park's speech is about science or that it is published by a scientist or that it constitutes the practice of science. The essential point is that Park's speech 
constitutes an effort to alter public knowledge and opinion. This point is applicable to some but not all scientific communications.

The question whether Park's website is constitutionally protected from regulation can not be answered solely by examining Park's website. The resolution of this issue requires balancing the constitutional value served by Park's speech against whatever interests the state may claim to be serving by enacting the Digital Millennium Copyright Act. It may be that these interests are not very important when weighed against the damage the Act causes to the public sphere. Or it may be that the government can serve these interests in ways that do not so extensively damage the public sphere. Or it may be that Park can distribute his speech to the public sphere in ways that advance public knowledge and opinion without compromising the interests served by the Act.

Other nations that protect speech overtly thematize this contextual approach in what is called "proportionality" analysis. In the United States there are many different First Amendment tests that are more or less explicit about such balancing. As a practical matter, however, American courts regularly engage in forms of reasoning that are roughly the same as the proportionality analysis that is common in other countries. That is why a great deal more information is needed to know whether Park's speech is actually protected from the application of the Digital Millennium Copyright Act. The fact that Park might be said to be engaged in "scientific speech" is at most of marginal relevance.

\section{Government Restrictions on Scientific Research}

Fundamental to all versions of First Amendment doctrine is the distinction between speech and conduct. Murder does not trigger First Amendment coverage, even if the murder is by a terrorist seeking to communicate a message of hostility. It is not the case that the distinction between speech and conduct depends upon properties in the world, such that all instances of "speech" have certain properties in common that instances of "conduct" do not, or visa versa. It is rather the case that those forms of behavior that serve the purposes of the First Amendment are classified as "speech." Parades consist of conduct, but courts will nevertheless classify parades as "speech" because they serve values protected by the First Amendment. They are recognized media by which public opinion is informed and engaged.

The point of distinguishing the regulation of "scientific speech" from the regulation of "scientific research" is that research seems to involve what most would regard as conduct. Yet different forms of scientific research will possess different constitutional properties that will raise different constitutional questions. A law banning the "research" of a mathematician, for example, would seem to prohibit reading and would for that reason likely trigger First Amendment coverage. A law banning the use of anthrax bacteria, by contrast, would likely not trigger First Amendment coverage, even though it may shut down the research of particular scientists. "Scientific research," in other words, is not a single, coherent constitutional category. It embraces many different phenomena that are differently connected to First Amendment values. 
A further complexity arises because First Amendment coverage can be independently triggered by the reasons for governmental regulations. Regulations adopted for improper reasons will trigger First Amendment coverage even if they do not apply to what might be classified as "speech." (Post 1995) First Amendment coverage will be triggered if the state prohibits research on animal populations in order to ensure that citizens will continue to believe in intelligent design. This is true even if the state might otherwise regulate such animal research for proper reasons, like animal safety, without triggering First Amendment coverage.

There are virtually endless permutations. That is why it is not useful to ask in the abstract whether there are constitutional constraints on government regulation of scientific research. Constitutional analysis will depend upon a great many diverse factors, none of which is particularly dependent upon whether the state is seeking to regulate science or a scientist. I suggest that in general there are three questions that are likely to prove useful in determining the constitutional dimensions of particular regulations:

1. What does the Proposed Regulation Seek to Constrain? The research of some social scientists consists entirely of interviewing persons. If the state were to enact a statute imposing criminal penalties whenever one person seeks to ascertain the race of another, the statute may effectively prohibit the research of a social scientist interested in correlating race to various social attitudes. Such a statute would likely trigger First Amendment scrutiny. This is not because the statute suppresses research, but because it prevents forms of communication that would otherwise merit First Amendment coverage. The constitutional question that would be presented by such a statute is whether private conversations about public matters are a constitutionally necessary component of the processes by which public opinion is formed.

A statute prohibiting the ascertainment of another's race should be contrasted to a regulation that prohibits possession of the smallpox virus. The latter regulation might effectively prohibit the research of a biologist who has spent a lifetime studying the virus. Yet it is highly unlikely that the statute would trigger First Amendment coverage, because the possession of the smallpox virus would not be considered constitutionally essential to the process of public opinion formation.

It might be tempting to ague that even though a prohibition on the possession of the smallpox virus might not trigger constitutional coverage on its face, it ought nevertheless to trigger First Amendment coverage as applied to a biologist who wishes to conduct research. The biologist who studies smallpox might argue that because his "research" carries independent constitutional value, the state cannot apply the regulation to his research without withstanding constitutional scrutiny. In effect, the biologist argues that even though a general prohibition of conduct might not trigger First Amendment coverage, its application to particular forms of behavior might perhaps trigger First Amendment coverage if there is a sufficiently important impact on relevant constitutional values.

This is a difficult question. As a general matter, the biologist's argument fails. A graffiti artist who mutilates public property with anti-government slogans cannot claim First Amendment coverage when general rules against the defacement of public property are applied to him. Neither can the terrorist claim First Amendment 
coverage for his destruction of the World Trade Center on the ground that he has caused explosions that were successfully designed to influence public opinion.

Sometimes, however, First Amendment coverage is triggered when general prohibitions of conduct affect what are the called "media for the dissemination of ideas." A general law banning the production of newsprint in order to conserve trees would trigger First Amendment coverage, because such a law would have a significant impact on the distribution of newspapers. Media for the communication of ideas, like newspapers, are generally understood to be constitutive of the public sphere and hence to merit constitutional protection. Because the public sphere is constituted by textual forms of communication, media for the communication of ideas are always communicative in nature. Scientific research is not communicative in this way and so would be unlikely to be constitutionally categorized as a medium for the communication of ideas.

2. What is the Purpose of the Proposed Regulation? A statute that applies only to conduct that does not trigger First Amendment coverage might nevertheless provoke constitutional scrutiny if sufficient suspicion arises that it has been enacted for a purpose that is not constitutionally proper. Often suspicion arises because a statute does not take the form of a general prohibition.

This difference was important to the United States Supreme Court when it considered the constitutionality of statutes that punish burning American flags (Texas v. Johnson 1989). Arson statutes that prohibit burning material in the streets do not trigger First Amendment coverage. A person burning rubbish in the street can be prosecuted under a general arson statute without triggering First Amendment scrutiny. So also can a person burning an American flag in the street be prosecuted under a general arson statute without triggering First Amendment scrutiny. This is the same principle as that we discussed in the case of the graffiti artist who may not raise a First Amendment defense to prosecution under a general law prohibiting the defacement of public property.

But many states enacted statutes that did not prohibit arson, but instead proscribed the burning of American flags. They prohibited flag burning in order to uphold the symbolic significance of American flags. The court concluded that this purpose was constitutionally improper. A person burning an American flag may thus be constitutionally immune from prosecution under a flag burning statute but not under a general arson statute.

Analogous considerations apply to scientific research. It is one thing for a state to enact a law that generally prohibits possession of the smallpox virus. It is quite another for a state to enact a law that prohibits research on the smallpox virus. The latter immediately raises the question of why the state has chosen to prohibit only research. Is it because the state wishes to inhibit the growth of knowledge? Such a purpose would be improper and therefore trigger First Amendment coverage. How a statute is framed is often a powerful clue about why it has been enacted. Statutes that single out and prohibit research as such may arouse strong suspicions of improper purpose.

3. What is the Source of the Proposed Regulation? State laws are paradigmatically imposed by statutes that apply to all persons within a jurisdiction. Sometimes, however, a state acts through particular institutions in ways that affect only certain 
classes of persons. A good example are state universities, which issue regulations that control the behavior of faculty but not of the general public.

Special constitutional rules apply when states seek to regulate the faculty of state universities. This is because the Court has held that academic freedom is a "special concern of the First Amendment, which does not tolerate laws that cast a pall of orthodoxy over the classroom." (Keyishian v. Board of Regents 1967) Chief Justice Warren has explained why the First Amendment protects academic freedom:

The essentiality of freedom in the community of American universities is almost self-evident. No one should underestimate the vital role in a democracy that is played by those who guide and train our youth. To impose any strait jacket upon the intellectual leaders in our colleges and universities would imperil the future of our Nation. ...Scholarship cannot flourish in an atmosphere of suspicion and distrust. Teachers and students must always remain free to inquire, to study and to evaluate, to gain new maturity and understanding; otherwise our civilization will stagnate and die. (Sweezy v. New Hampshire 1957).

This reasoning applies to the regulation of scholarship. It does not distinguish scientific research from any other form of scholarship. It follows, however, that regulations imposed by state universities on scientific research may be susceptible to challenge on the ground that they impinge on constitutionally protected academic freedom. This is not about science; it is a point about scholarship. State university regulation of scientific research will be governed by the same general principles as would control the constitutional analysis of any state university regulation of scholarship.

\section{References}

Keyishian v. Board of Regents. (1967). 385 U.S. 589, 603.

Post, R. (1993). Between democracy and community: The legal constitution of social form. Democratic Community, NOMOS XXXV, 163-190.

Post, R. (1995). Recuperating First Amendment doctrine. Stanford Law Review, 47, 1249.

Post, R. (2000a). The constitutional status of commercial speech. UCLA Law Review, 48, 1.

Post, R. (2000b). Encryption source code and the First Amendment. Berkeley Technology Law Journal, 15,713 .

Post, R. (2000c). Reconciling theory and doctrine in First Amendment jurisprudence. California Law Review, 88, 2355.

Sweezy v. New Hampshire. (1957). 354 U.S. 234, 250 (plurality opinion of Warren, C. J.).

Texas v. Johnson. (1989). 491 U.S. 397.

Weinstein, J. (2009). Democracy, individual rights and the regulation of science. Science and Engineering Ethics (this issue). 